\title{
YAŞAR KEMAL VE DİDO SOTİIIYU ROMANLARINDA BELLEK UĞRAŞI OLARAK TÜRK- YUNAN NÜFUS MÜBADELESI
}

\author{
THE TURKISH-GREEK POPULATION EXCHANGE AS A MEMORY STRUGGLE \\ IN THE NOVELS OF YAŞAR KEMAL AND DIDO SOTIRIOU
}

\section{Christina ZENGINOĞLU* - Nihayet ARSLAN**}

\begin{abstract}
ÖZ: Savaş, kırım ve sürgünler yaşamış insanlar, tanıklık ettikleri acılı süreçleri tarihe not düşmek amacıyla anlatmaya çalışmışlar ve bunu değişik yöntemlerle yapmışlardır. Yaşanılan travmatik geçmișler ve negatif anılar sanatsal ve düșünsel üretimin dayanağı kabul edilmiștir. Yeryüzünün farklı bölgelerinde yașanan acı ve kayıpların bilinmesi sahada olmayı, kayıtlar tutmayı ve sözlü anlatıları derlemeyi gerektirmiștir. Gerçekleșenlerin aktarımı günlükten otobiyografiye nakledilme alanı bulurken unutturmama hususu gündeme yerleșmiștir. Savaș mağdurlarının, kaçakların, esir ve göçmenlerin beyan ve anıları başvuru kaynakları olmuștur. Bu çalıșmada geçmiş bir dönem veya hadiseyi sosyal dolaşıma sokabilmek için romanları hatırlatıcı araçlar olarak değerlendirmenin mümkün olduğunu tartışacağız. Anadolu doğumlu bu iki yazarın kurgusal kesişimleri ve bellek aktarımları, Türk- Yunan Nüfus Mübadelesinin (1923) neden olduğu sosyo-kültürel spazmları karşılaştırmalı şekilde tahlil etmemize olanak tanımıștır. Bu çalışma, mübadelenin zorunlu bir tahliye olması nedeniyle diğer göç türlerinden farklı olarak, romanlarda hangi yönleriyle dile getirildiğini ve bunun sosyal belleğin canlanmasına olası etkisini inceler. Burada amaçlı örneklem için eşleștirdiğimiz Yaşar Kemal'in Bir Ada Hikâyesi başlıklı roman dörtlüsü ile Dido Sotiriyu'nun I Nekri Perimenun ve Matomena Homata romanlarının dışında bu zamana kadar hiçbir akademik mecra ve yayında anılmamış bir otobiyografinin çalışmamız için tamamlayıcı olduğunu belirtmek gerekir. Gerçek bir kiși olan Manolis Aksiyotis ve tanıklığı, kurmacada tanıklık kullanma durumundan romanda tanık göstermeye kadar birçok noktayı yanıtlamamıza olanak vermiş, bilişsel bir kaydın kurgusal kaydı dönüştürse de aslını bozmayabileceğini görmemizi sağlamıştır.
\end{abstract}

Anahtar Kelimeler: Türk Yunan nüfus mübadelesi, Yaşar Kemal, Dido Sotiriyu, roman, hatırlatma.

ABSTRACT: The remnants of the war, massacre and exile have tried to testify by various means. Traumatic past and negative memories have inspired artistic and intellectual works. Knowing the pain and losses experienced in different parts of the world required being in the field, keeping records and collecting oral narratives. While the transfer of what happened is possible trough various means from diary to autobiography, the issue of not being forgotten is on the agenda. Testimonies and memories of war victims, fugitives, prisoners and immigrants have been reference sources in the process. In this study, we will argue that novels can serve as reminder

\footnotetext{
${ }^{*}$ Yıldız Teknik Üniversitesi Sosyal Bilimler Enstitüsü Türk Dili ve Edebiyatı Anabilim Dalı Doktora Programı Öğrencisi/İstanbul - zenginoglutina@gmail.com (Orcid ID: 0000-00027820-6143)

** Prof. Dr. - Yıldız Teknik Üniversitesi Fen-Edebiyat Fakültesi Türk Dili ve Edebiyatı Bölümü / İstanbul - nihayet.arslan@gmail.com (Orcid ID: 0000-0003-2459-2891)

This article was checked by Turnitin.
} 
tools of a lost period or forgotten events by promoting their social circulation. The fictional intersection and memory transfers of two Anatolian-born writers has allowed us to analyze the reciprocal socio-cultural spasms caused by the Turkish-Greek Population Exchange (1924). The text analyzes the aspects and ways in which population exchange- which is a forced migration and thus stands apart from other types- is brought back in novels as well as its effects on social recall. Besides Yaşar Kemal's quartet titled Bir Ada Hikâyesi and Dido Sotiriyu's I Nekri Perimenun and Matomena Homata, which are matched with purposeful sampling here, we can study an autobiography that has not been mentioned in any academic media or publications until now. It should be noted that it is complementary. Manolis Aksiotis, who is a real person, and his testimony have allowed us to address many issues from using testimony in fiction to showing witnesses in the novel, allowing us to see that a cognitive record may not distort the original event even when it transforms a fictional record.

Keywords: Turkish-Greek Population Exchange, Yaşar Kemal, Dido Sotiriou, novel, reminding.

\section{Giriş}

Kurmaca ve kurmaca dışı edebi türlerde geçmişi yaşatma, yaşananı kalıcılaştırma amacıyla pek çok metin yazılmıştır. Dünden bugüne bütün edebiyatlarda bu türden eserlere rastlamak mümkündür. Döneme tanıklık eden bu tip eserlerin değerlendirilmesi, düne ait fotoğrafların tespitine yönelik birçok yöntemin gelişmesine zemin hazırlamıştır. Totaliter rejimlerin ardından kalan ses ve görüntü arşivleri, tanık notları, göçmen ve mübadil günceleri "anlatılamayanın” kaynaklarını oluşturmuştur. Dünyanın çeşitli yerlerinde ve değişik dönemlerinde kayda alınanların olumsuz duygusal yükün unutulmamasında ve mümkünse bundan ders çıkarılmasında önemli bir rol üstlendiği görülmüştür.

Savaş ve kamp deneyimlerinin ön planda olduğu bu kayıt ve yazılarda öznenin bir şeyleri iletmesi söz konusudur. Travmatik bir geçmişte biriken anlatıların bir diğer ortaklığı da kurbanları işlemeleridir. Hatırda tutmaya dönük söz konusu girişimler sembolik olmaları ve kamusal bir duyarlılık yaratmayı amaçlamaları bakımından da ortaklaşırlar. Bu çalışmada türü romanla sınırlı tutarak, romanları mekânlar ve eşyalar gibi hatırlatıcı araçlar olarak değerlendirmenin mümkün olduğunu açıklamaya çalışacağız. Bilindiği gibi hatırlama ve unutma iç içe gelişen bilinç durumlarıdır. Bellek, Türk Dil Kurumu'nun sözlügünde (1988:167) yaşananları, öğrenilen konuları, bunların geçmişle ilişkisini bilinçli olarak zihinde saklama gücü şeklinde açılklanır. Bu tanımlama; saklama, kodlama ve çağırma gibi belleğin bilişsel işlevleriyle sınırlıdır. Ancak hatırlamanın ve karşı durumu unutmanın dışsal bir bağlamı da vardır (Assmann, 2015: 26-27). Bunun temel sebebi kişinin sosyal bir varlık olmasıdır. Diğer bir ifadeyle birey, bilişsel anlamda bir zihne sahipse de burada yer edenlerin toplumsal yönlendirmeleri söz konusudur.

Toplumdan kasıt aynı toprak parçası üzerinde bir arada yaşayan ve temel çıkarlarını sağlamak için iş birliğinde bulunan insanlar bütünü (TDK, 1988: 1484) ise, birden fazla insanın amaçlı bir șekilde paylaşıma geçmesi müșterek bir zemine vurgu yapar (Halbwachs, 2018: 28). Burada çoğulculuk 
ve bulaşıcılık bakımından aslında durağan olmayan bir olgudan bahsederiz. Her hatırlamanın başka birçok kimsenin sahip olduğu düşünceler kümesiyle ilişkili olduğu ve toplumun maddi-manevi yaşamlarıyla eş süremli gerçekleştiği görülür (Connerton, 2014: 60). Başka bir deyişle kişinin hatırlamasını zorlayan harici bağlam geri getirmeyi veya itmeyi belirler. Zihinsel süreçlerin ayıklama sonucu yüzeye çıkarttıkları sadece kişisel yaşantılara ve anılara yönelik değildir (Hirsch, 1997: 24). Bireylerin ve toplumların geçmişlerini, kültürel yaşamlarını ve yaşadıkları çalkantıları hatırlama fakat aynı zamanda hatırlatma vasfına sahip olan romanlar, gerek teknikleriyle gerekse anlatısal formlarıyla tamamlanmış bir kesiti veya durumu geri getirebilirler. Daha açık bir anlatımla roman, hatırlama özneleri kadar hatırlatma nesnelerine yaşama imkânı sunan iletişimsel bir sahadır. Başka bir zamanda meydana gelmiş herhangi bir olayı tekrar yoluyla dolaşıma sokarken hatırla(t)maya müstakil bir çerçeve çizer. Roman toplumun sapmalarına dikkat çektiği gibi bu sapmaların aşamalarına ve bileşenlerine de ışık tutar. Geçmişi anlama çabasında istikamet tayin etmesiyle roman aslında yapay bir bellek kurar. Kaydetme ve iletme pratiğiyle bireysel deneyimin olmadığı ve olamayacağı koşullarda dolaylı bir bilgilendirmeyle, söz konusu deneyimin edinilmesine aracı olur ve bir hatırlatma dokur.

Tanık durumunda olan ana karakterin yazarla, yazarın da roman üzerinden okurla paylaştıkları her şeyden önce bir aktarımdır. Burada, yaşanılan veya sonradan işitilen şeylerin, bir şeylere mecbur bırakan durumların, koşulların sonrakilere devredilmesi söz konusudur. Gelinen nokta bireyseli aşan ve kamusal olarak şekillenen hatırlamaya yöneliktir. Başka bir ifadeyle geçmişin şimdide ve yeniden inşasında hatırlama kadar hatırlatma da dişsal tesirlere açıktır. Geri getirilen kayıt ise her şekilde başkalaşmış bir içerime sahiptir. İleri sürdügümüz görüşle söyleyecek olursak, roman hatırlama gibi unutma durumu için de bir taşınırlık sağlar (Wegner vd., 1991: 923-929). Tarihsel gerçekliğin göz ardı ettiği/etmek zorunda olduğu pek çok açıyı yeni bir oluşta aktarır. Bireysel ve toplumsal acıların, yas halinin ve nicesinin yitmemesini, yaşanan ya da yaşatılan eşsiz benzersiz deneyimlerin ana anlatıya feda edilmemesini mümkün kılar. Resmi belleğin oldukça uzağında şekillenen bir doğa kuran roman, sosyal hatırlamanın değişkenlik gösterebileceğini, bireylere ve toplumlara mahsus belleklerin canlı olabileceğini ve bunların mutlak șekilde otoritelerce yontulmayabileceğini düşündürür.

Çalışmamız, 1923 yılında gerçekleşen ve gerek Türkiye gerekse Yunanistan toplumlarında geri dönüşsüz deneyimlere neden olan TürkYunan Nüfus Mübadelesi özelinde hatırlamanın ve/ya unutmanın kurmaca inşasını tespit etmeyi amaçlar. Diğer bir deyişle roman ile kurulan ikinci buna yansıma doğa da denebilir- doğanın ne şekilde kurulduğuna yanıt aramayı dener. Amaçlı bir örneklem için eşleştirdiğimiz Yaşar Kemal'in Bir 
Ada Hikâyesi ${ }^{1}$ başlıklı roman dörtlüsü ile Dido Sotiriyu'nun İ Nekri Perimenun $^{2}$ ve Matomena Homata ${ }^{3}$ romanları, türün özgün bir anımsa(t)ma edimi ortaya koyabileceğini ve belleklerarası bir düğümleme sağlayabileceğini tartışmaya açar. Burada belirtmemiz gereken bir ayrıntı da Matomena Homata romanının anlatıcı karakteri olan Manolis Aksiyotis'in hiçbir akademik yayında ele alınmayan Berdemeno Kuvari ${ }^{4}$ ve Enomena Valkania $^{5}$ başlıklı iki kitabının olduğudur. Romandan yıllar sonra savaşta ve mübadil olarak yerleștiği Atina'da tanık olduklarını kaleme aldığı, neredeyse birbirini tekrarlayan iki metin özel bir baskıyla birleștirilmiştir. Bütünleşik şekilde Ĕgo, O Manolis Aksiyotis adıyla yayımlanan otobiyografi, Matomena Homata romanına ne ölçüde yön verdiğini saptamak için derinlemesine çözümlenmiştir. Dönemin olaylarını yaşamış bir liman emekçisinin kendi defterini yazara götürmesiyle romanda kurgulanmış olanlar gibi, Manolis Aksiyotis'in emekli olmasıyla bizzat kendisinin doğrudan yazmaya koyuldukları yaşanılanların bellek haritasını çıkarmamızı kolaylaştırmıştır.

Savaş, kıtlık, sürgün gibi oldukça sancılı deneyimler, hatırlamayı ve hatırlamanın tutunduğu düşünsel çerçeveyi şekillendirir. Negatif anıya maruz kalmanın fiziksel, psikolojik ve kültürel boyutu zihnin geri çağıracakları gibi baskılayacaklarını da belirler (Creet ve Kitzmann, 2011: 76). Bu bağlamda çalışma için ele alınan yazarlar olan Yaşar Kemal ve Dido Sotiriyu benzer geçmiş örüntülerinden geçerler. Birinci Dünya Savaşı'nda Rusların Van'ı işgal etmesiyle göç etmek durumunda kalan Göğçeli ailesi ile yüksek makamlardaki dostları aracılığıyla Yunan Ordusunun İzmir'e asker çıkarmaya hazırlandığından vakitlice haber alan ve devletlerarası ilişkiler tırmanışa geçmeden Atina'ya göç eden varlıklı Pappa ${ }^{6}$ ailesinin çocuklarını birleştirir. Birinci kuşağın negatif anılarını devralmak gerek Yaşar Kemal'in gerekse Dido Sotiriyu'nun görüş ve yazın evrenine tesir eder. Yaşar Kemal, Dido Sotiriyu gibi yaşananları doğrudan deneyimlemese de anne ve ninesinden dinlediklerinin düşüncelerine yön verdiği anlaşlır. Zikredilen durumların keyfi olmaması ve bir mecburiyet sonucunda yaşanmaları önceki kuşağın naklettikleriyle kesişir. Anadolu coğrafyasında çatışmanın nihayete eremediği son derece hareketli yılların paralel anlatımı ve bu anlatıların travmatik belleklere sahip kesimlere ses olma istekleri

1 Dizideki romanlar ve yayın yılları şu şekildedir: Fırat Suyu Kan Aklyor Baksana 1998, Karıncanın Su İçtiği 2002, Tanyeri Horozları 2002 ve Çıplak Deniz Çıplak Ada 2012.

Firat Suyu Kan Aklyor Baksana, Panayot Abacı tarafından I İstoria Enos Nisiu: O Kserizomos başlığıyla Yunancaya aktarılmıştır. Çeviri 1999 yılında Themelio Yayınları'ndan çıkmıștır.

2 İ Nekri Perimenun 1995 yılında Kriton Dinçmen tarafından Ölüler Bekler başlığıyla Türkçeye çevirilmiş, Arion Yayınları'ndan çıkmıştır.

3 Matomena Homata, 1970 yılında Atilla Tokatlı tarafından Benden Selam Söyle Anadolu'ya ismiyle Türkçeye aktarılmıștır. Çevirisi önce Sander Yayınları daha sonra Yeni Alan ve Can Yayınları tarafından da yayımlanmıştır. Çalışmamızda Yunanca eserlerin tümü, Christina Zenginoğlu tarafından Türkçeye çevrilmiştir.

${ }^{4}$ Dolaşı k Yumak olarak Türkçeye çevirebiliriz.

${ }^{5}$ Birleşik Balkanlar olarak Türkçeye çevirebiliriz.

${ }^{6}$ Dido Sotiriyu'nun kızlık soyadı. Yazar eşi Platon'un soyadıyla tanınmıștır. 
yaratılarını yerleşik anlatıların haricinde bırakır. Çocukluk ve gençlik yıllarının manevi endişeleri yazarları toplumsal bir fayda için çalışmaya teşvik etmiş, onları söz hakkı tanınmayan çevrelere ve bu çevrelerin yaşamlarına alaka göstermeye yönlendirmiştir.

Yaşar Kemal ve Dido Sotiriyu'nun seçilmiş travma olarak Türk-Yunan Nüfus Mübadelesini kurgulamaları ve sosyal bir tarihe yönelerek alternatif analiz düzeyleri aramaları onları sözlü anlatılara yer verme noktasında da buluşturur. Bunda gazete ve dergicilikte etkin oluşlarının payı olduğunu söylemek yanlış olmaz. Gelişmeleri sıcağı sıcağına takip edebilme imkânları, canlı tanıkların gözlem ve ifadelerini kaydetmelerini sağlar. Kapalı tarih yazımı ve arşiv menşeli belgelerin dışında sosyal bir gerçekliği tetkik etme ve yeniden kurma girişimleri onları sürekli yapılanan sivil tarihe taşır. Burada iki yazar için de "kullanışlı bir geçmişten" (Boyer ve Wertsch, 2015: 156) hareket etmedikleri söylenmelidir. Kullanışlı olmayan bu geçmiş kurgusunun mübadele gibi bellek örgülenimlerine de yansıdı̆̆ sezilir. Tarihsel kayıt ve söylemlerin uzağında toplumsal kesimlerin anlatılarında bir araya gelen yazarlar, resmi olanın sebep oldukları kadar bunun yarattığı kalıp yargılara da odaklanırlar.

Bireysel ve toplumsal belleğin kaynaşma sonucu oluştuğunu (Barnier ve Sutton, 2008: 177) ve bu kaynaşmanın kurgusal alanda ortaya çlkan konvansiyonel tahliyesini, atomik ve kolektif hatırlama eksenli olarak izaha çalışacağız. Bir Ada Hikâyesi'ne kıyasla erken bir dönemde yayımlanan $\dot{I}$ Nekri Perimenun ve Matomena Homata romanları savaşlar ve göçler öncesi Anadolu ve Anadolu kimliğine dair ciddi izlekler sunarlar. Bir Ada Hikayesi'nde Türk Yüzbaşı Poyraz Musa'nın Yunanca adıyla Mirmingi'ye gelmesinden, Lena Papazoğlu ve bir hayalet gibi kendisini izleyen Vasili Atoynatanoğlu ile dostluk kurana kadar geçen sürede Rum nüfusun geride bıraktıkları belirginleşir. Geveze berber Nuri'nin dükkânına gelen üniformalıya anlattıkları uluslararası ticaretin kaynağı hakkında bilgiler verir. Her ne kadar anlatıcı mübadele sonrası kalanlara, izlere yoğunlaşsa da burası Ortodoks ile Müslüman nüfusun bir arada çalıştığının, iç içe ürettiğinin betimlendiği Dido Sotiriyu'nun bölümleriyle paralellik gösterir. Kültürel geçirgenlik kadar sosyal bir akışkanlığın öne çekildiği romanlarda toplumsal ilişkilerin savaş sebebiyle bozulduğuna dönük vurgular üç anlatıcı için de geçerlidir. Aliki Maği ve Manoli Aksiyotis'in, Bir Ada Hikâyesi'nin anlatıcısıyla geçmişi geri getirme noktasında sık sık aynı duraklarda beklediklerine şahit olunur.

Rumların Yunanistan'a gönderileceği ada sakinleri için kabulsüz bir durumun olduğunu en ince teferruatına kadar işleyen Yaşar Kemal, kasabadaki ve civar köylerdeki pek çok esnafa iş öğreten kesimin gidemeyeceğini, niçin gitmemesi gerektiğini dokur. Panosaki gibi yediden yetmiş̧e herkese balıkçılığı öğreten usta bir balıkçının sürülmesinin ayıbını, artık yaşamayan farklı meslek gruplarının temsilcilerine çektiği dikkatle açıklamaya çalışır. Buradan bakıldığında Dido Sotiriyu romanlarına göre 
politik bir karara dostluk ve komşulukla itirazın yükseldiği gözlenir. Mübadeleyi ele almada periyodik farklılıklar söz konusuysa da bunun bireysel ve toplumsal bellekte açtığı yaraları sıralama konusunda romanlar ortak bir özelliğe sahiptir. Diplomasi bağlamında çatışma durumundan müzakereye geçiş, devletlerarası görüşmeler, konsensüs ve nicesi siyasal anlamda önerilirken iki yazarın süreç hakkındaki düşünceleri birbirinden bir hayli farklıdır. Yazarların mübadeleye savaşa son verecek yapıcı bir çözüm olarak yaklaşmadıkları açıktır. Onlar için mübadele insanlık için telafisiz bir dönemeçtir. Nitekim savaş karşıtı romanlarında bu büyük tahliyeyi savaştan ayırmadıklarına ulaşılır.

Zorunlu göçlere -özelde mübadeleye- yaslanan romanlarda, farklı etnik kimliklere sahip insanlara hatırlama ve unutma unsurlarının kazandırılması dikkat çeker. İki yazarın da muhtelif baskı, yasak ve işkenceleri işledikleri romanlarında savaşın bir insanlık suçu olduğu yinelenir. Türk- Yunan Nüfus Mübadelesi iki yazar için de toplumsal yaşam için betimlenen uyumun, iş bölümlü yaşam alanlarının ve alışkanlıkların hasar görmesidir. Manolis Aksiyotis'in otobiyografisi gibi romanlarda da, bireysel hatırlamaların zamana ve mekâna atılan düğümlere içkin olduğunu, anlatıcıların kurgu yoluyla geri getirdiklerinde bir geçmişin ve yaşanmışın olduğunu, bu geçmişin devletlilerin müdahalesi ve müsaadesiyle örüldüğünü, arada kalan toplumların ve halkların böylesi bir yıkıcılığı ve bölünmeyi tercih etmediklerini okuruz. Hiçbir irksal veya dinsel hizaya çekmeksizin kitlesel bir burukluğun nasıl hatırlandığını -ya da unutulduğunu- sosyal grupların düşsel, düşünsel ve tepkisel hareketliliğini esas alarak yeniden okuma uğraşına girişen iki yazar, ortak geçmişin nasıl geri çağrıldığına ve bu çağrıda nelerin öne çıktığına yönelir.

Romanlar bireyin içinde bulunduğu toplumsal bağlamın kıstaslarını biçerken hatırlamanın karşılıklı işleyişini belirginleştirirler. Yapılandırdıkları post bellekle nesiller arası bir farkındalı zinciri oluştururlar. Yazarlar politik bir uygulamanın yüzyılların geleneklerini kıramadığını, iki toplumun insanlarında da geçmişlerinden mutlak surette bir şeylerin kaldığını gözler önüne sererken, hatırlamayı tetikleyenin de kalan bu tortuların olduğunda anlaşırlar. Karakterlerin çaresizlik anlarında dillerinden düşürmedikleri Türkçe ve Rumca deyimler ve birbirlerinin konukseverliğini aramaları, hatırlama çerçevesinden çıkılamadığının en haiz örnekleridir.

\section{Bellek Uğraşı: Türk-Yunan Nüfus Mübadelesinin Örülümü}

Geçmiş süresiz bir dönüşüm içerisindedir. $\mathrm{Bu}$ dönüşümü gözlemleyebileceğimiz en işlek alanlar, sosyolojik gözeler olarak niteleyebileceğimiz romanlardır. Romanda ikinci bir doğanın kurulumu söz konusudur. Bu kurulumda, okuyucu yitmiş bir süreç veya kesitte bulunan ana çekilir ve artık yaşananla değil, bunun temsiliyle karşı karşıya kalınır (La Capra, 1998: 72). Daha açıklayıcı olmak gerekirse yitmiş bir zihinsel kaydın canlandırmayla şimdiye çağrıldığı söylenebilir. Başka zamanda meydana 
gelmiş ve son bulmuş bir durum veya olayın tekrar yoluyla hatırlanması fakat aynı zamanda hatırlatılması Dido Sotiriyu'nun deyimiyle bir "bellek uğraşıdır."7 Bahse konu edilen bellek uğraşında tamamlanmış bir zamanı geri çekmek vardır. Böyle bir öneri, yaşanılan zamana tutturulacak olanın tüm boyutlarıyla işlenmesini, bunun geçmişte ne surette öne çıktığını ve bıraktığı izi bilmeyi gerektirir. Görüldüğü gibi yaşanmış, yani esas doğa yeni bir oluşa hareket noktası olur.

İki yazarın da her anlamda klasik göç çeşit ve tasniflerinin dişında kalan ve kapsayıcılık bakımından iki devletin dinsel azınlıklarıyla sınırlandırılmış mübadelenin sosyal boyutuyla ilgileneceklerini ve yaşayanların hatırlamalarına eğileceklerini ifade etmeleri, romanları karşılaştırmalı bir şekilde değerlendirişimizi imler. Kurgusal tekrarların süresi tamamlanmış aynı olayda buluşması, metinler arası bir ölçme yapmamıza olanak tanımıştır. Ölçmeye tabi tuttuğumuz örnek hadise, romanlardaki bağlaşıklık ve yoğunluğa göre ele alınmıştır. Çalışmamız, romanın kolektif hatırlamayı tayin edebileceğini, hatırlamayı standardize edebileceğini, böylece okurdan okura "bellek dügümleri" atabileceğini ileri sürmektedir (Rothberg, 2009: 5). Buna göre bu çalışma, romanın çift durumlu bir hatırla(t)ma ortaya koyabileceğini, -Manolis Aksiyotis'te olduğu gibi-bunun kişisel deneyimlerle biçimlenebileceğini, dolayısıyla anısal bir içerime sahip olabileceğini; ayrıca kişinin birebir tanık olmadığı, öğrenmeyle gelen kültürel bir hatırlamayı verebileceğini tartışmaktadır. Bu açı iki şeyi merkeze alır: Hatırlama öznesinin kim olduğunu ve hatırlananın neyin olduğunu (Ricoeur, 2017: 22).

Bilindiği üzere 93 Harbi sırasında Osmanlı toprakları olan Romanya ve Bulgaristan'da yaşayan Rumlar Yunanistan'a, Türkler ise Anadolu topraklarına sürülmüştür. Sonraki dalga Balkan Savaşlarıyla gelmiş, Batı Trakya'da bulunan Türkler Anadolu topraklarına; Ortodoks Rumlar da Yunanistan'a tahliye edilmiştir. Sürecin resmi bir boyut kazandığı Lozan Barış Antlaşması'yla iki devletin dinsel azınlıkları karşılıklı ve zorunlu bir göçe tabi tutulmuştur (Bozdağlığlu, 2014: 10). Avrupa'nın öneri ve gözetiminde gerçekleșen tek yönlü ve dönüş yasaklı süreci hatırla(t)mak maksadıyla müzecilikten sergiciliğe alternatif yollar aranmıştır.

Daimî bir esasa dayalı bu biricik tahliye edebiyatta da yerini bulmuştur. Roman yönelimli baktığımızda Yunan romanında beliren oldukça erken tarihlerin aksine, hadise Türk romanında doksanlı yıllarda görülmeye başlanmıștır (Arı, 2017: 11). Bunun mebzul tarihsel, demografik, ekonomik ve siyasal sebepleri olduğuna dikkat çeken Herkül Millas (2005: 337), Yunan romanının oluşmaya başladığı 1830'lu yıllarda Yunan devletinin merkezi eğitim sisteminin yaygınlaşmış olduğunun, ulusçu

\footnotetext{
7 Başlık seçiminde bizi ikna eden de yazarın notlarında "belleklerin canlı bir uğraş sahasının olduğunu" okumamız olmuştur. Değișimin doğrudan bir bellek durumu olduğu dikkate aldığında başlığın her firsatta "değişimlerin romancısı olduğunu" belirten Yaşar Kemal'e de uygun düşeceği düşünülmüştür.
} 
söylemin halk nezdinde çoktan karşıllk bulduğunun; Osmanlı/Türk romanının ortaya çıktığı dönemde ise ulusal devletin henüz kurulmadığının altını çizer. Edebiyattaki hassasiyetlerin de bunlardan bağımsız okunamayacağını vurgular. Açık olan iki farklı grup "bilincinin" edebiyat metinlerinde egemen olduğudur (Millas, 2000: 330) Türk ve Yunan romanındaki farklılıklara yoğunlaştığı diğer bir çalışmasında Millas (2005:130-131), Türk tarafındaki görece ilgisizliği Türklerin geride bıraktıkları topraklarını, anılarını koruması ve onları kayıt altına alma gibi bir girişimlerinin olmamasına dayandırır. Diğer bir yaklaşıma göre ise Türk devletinin yaşadığı birçok travmatik aşama bu gecikmeye sebep olmuştur. Türklerin yeni yurtlara intibak evresi mübadele yazınını ötelemiştir. (Atıf ve Kumsar, 2018: 28)

İki toplumun eş acılarını dile getirmedeki dikkate değer bu periyodik aralığı iki durumla açıklamak mümkündür: Yunan Ordusu'nun İzmir'e asker çıkarmasının Küçük Asya'da (Anadolu) yaşayan Ortodokslar için demografik hareketliliği mübadelenin öncesine çekmesi ve meselenin Türk ve Yunan yazarlarda benzer karşılıklarının olmaması. İlk dairede yeni devletin, yani Cumhuriyet'in yerleşmesi varken ve bunun için beka, güvenlik ve ulusal inşa baskınken, diğer daire için asırlık bir idealin Meğali İdea'nın (Büyük Ülkü) sonuna gelindiğinin anlaşılması ve bunun yarattığı ulusal yas vardır.

Yaşar Kemal bir yazısında Auschwitz'in Güneybatı Polonya'da küçücük bir şehir olmasına karşın insanlığın yüzkarası olduğunu anlatır (Kemal, 2019: 79). Kamplarda yaşananlar ve yaşatılanlar anlaşllacak ve anlatılacak gibi değilse de edebiyatın bu benzersiz insanlık suçlarını dolaşıma sokmaktan yana olduğunu yazar. Aynı inanç onu yüzyılları ve coğrafyaları aşan bir bellek uğraşına çağırır. Böylece okurda duygusal sarsıntılar yaratacak imgesel bir mekân tasarlar. Bir şekilde insanlık suçlarına bulaşmış veya bundan son anda kurtulmuş özneleri bir adaya, Karınca'ya getirmekle dayanışmacı bir topluluk kurar ve karakterlerin geliş süreçlerine yaptığı dönüşlerle "hatırlamalarına" imkân tanır. Hayal, sanrı ve kâbuslar aracılı̆̆ıyla duraklatılan ve böylece büyüyen geçmiş, savaş ve göç gerçeğini yeniden düşündürür. Yazarın 1915-1925 yıllarının panoramik anlatımından çok, zikredilen yıllarda nelerin anlatılmadığını kurgulamaya gittiği söylenebilir. Yaşar Kemal'den ayrı biçimde Türk-Yunan Nüfus Mübadelesinin başına, Yunanistan toplumunun "Küçük Asya Felâketi" olarak adlandırdığı döneme ve bunda öne çıkan etken ve aktörlere odaklanan Dido Sotiriyu, yazınsal istikametini öznel ve kolektif hatırlamalara bina ederken Yaşar Kemal'de gözlenmeyen bir yüzleşme talebinde bulunur. Söz konusu açı Yaşar Kemal'in dörtlüsünde insani bir sorumluluk şeklinde öne çıksa da Dido Sotiriyu, hatırlama sorumluluğunu farklı bir boyuta taşır. Emperyalist güçlerin kazanç amaçlı ikircikli siyasetini ifşa özelliği İ Nekri Perimenun ve Matomena Homata romanlarını Bir Ada Hikâyesi'nden ayırır. 
Yaşar Kemal adaya bir kez gelenlerin korku, kaygı, tereddüt gibi nedenlerle geri gidişlerini, gidenler arasından kimilerinin uzun arayışlar sonucu yeniden dönüşlerini; kimilerinin alışmaya daha yatkın oluşunu, kimilerinin ise bunu israrla reddedişini açarken Dido Sotiriyu, kurguda politikacılara değinerek yer yer siyasi bir hesaplaşmaya gider. Öyle ki mübadillerin ve mağdurların yaşadıkları ikinci planda kalır. Bu noktada Yaşar Kemal'in yerleștirici ve unutturucu, Dido Sotiriyu'nun ise tekrarlatıcı ve hatırlatıcı olduğu denebilir. Her iki yazarın ortak noktası, geçmişten ve yaşananlardan ders çıkarılması, sebep olanların kınanması olarak saptanır. Buna rağmen yüzleşmenin Yaşar Kemal'in dörtlemesinde Dido Sotiriyu'nun iki romanındaki kadar radikal olmadığı, kendisinin bir devamlılıktan yana olduğu fark edilir. Onun için, sosyal hayattan türlü ihtiyaçlara ve taleplere karşılık bir devamlılık, bir yürütme durumu esastır. Yaşar Kemal, açık açık bir hesaplaşma teklifinde bulunmak yerine yarattı̆̆ gönüllülük üzerinden bir sürdürülebilirlik inşa eder.

Dido Sotiriyu, ilk romanı olan ve 1959 yılında yayımlanan İ Nekri Perimenun'u günümüzdeki vekâlet savaşlarını andıran bir kurguya dayandırır. Aydın'ın gözde ailelerinden Mağiler'in adım adım yok oluşunu çıkar politikalarıyla açımlarken, sabun fabrikatörü babanın savaşın henüz arifesindeyken her şeyini kaybedişini, buna karşın kuzeni Aristidis Bayındıroğlu'nun ani yükselişini orantısız sömürüyle bağlantılar. Matomena Homata romanında bu çabanın ileri bir boyutta Giritli bir üniversite öğrencisi olan Nikitas Drossakis'in Manolis Aksiyotis ile girdiği sohbetlerinde sürdüğü fark edilir. Emperyalist bloğun sosyalizmle aşllabileceği tasavvuruna Yaşar Kemal'in dörtlüsünde rastlanmaz. Bu detayıyla Bir Ada Hikâyesi, Yaşar Kemal'in diğer romanlarında işaret edilen seçilmiş sınıfın -ki bu ezilen işçi sınıfıdır- dışında kalır. Emekçi sorunlarının oldukça uzağında, kendisi için yeni bir coğrafyaya ve sınır ötesine uzanır. Buradan yaklaşıldığında mübadeleyle gelen faciaların ve iki milyon insanın korkunçluğu nitelediği evrenin hiçbir şeyin gölgesinde kalmasını istemediği düşünülebilir.

Dido Sotiriyu romanlarında ise mübadelenin görünür bir arka plana dayandırıldığına ulaşılır. Emperyal kuvvetlerin amaç ve niyetlerini, politik etkilerinin doğrudanlığını, roman karakterlerinin bakış açısıyla görme ve kavrama imkânı buluruz. Yaşar Kemal'de karşılaşmadığımız bir özelliktir bu. Bir Ada Hikâyesi'nde nüfus mübadelesi insanların ve toplumların başına gelir, kaynak sezilse bile bütünüyle ortaya getirilmez.

Hatırlayan öznenin hikâyesinin ön planda olduğu romanlar, bilinç akışı yöntemiyle geçmişi şimdide kurgulamakta ve aktarmaktadır. Belleğin aracı "mimesis" ile tarihi bir evre taklit edilir ve kurmacada değişik bir boyutta hayat bulur. Gerçekliğin yeniden yaratılmasıyla Balkan Savaşları, özellikle Birinci Dünya Savaşı ve sonrasında tepetaklak olan TürkiyeYunanistan ilişkileri, belleğin anlatım biçimlerinden olan mecaz, kinaye, alegori ve sembollerden yararlanılarak yeniden örülür. İstençli bir 
hatırlamayla Aliki Maği de Manolis de çocukluğuna, Aydın ve İzmir'deki yaşamlarına, barış hayatı olarak niteledikleri savaşlar ve göçler öncesine uzanarak bir hakikati yüzeye çıkarırken bireysel deneyimlerden toplumsal deneyimlere varırlar. Başka bir ifadeyle küçük fotoğraftan büyük fotoğrafa, özneden topluma ve böylece olayların sebep olduklarına ulaşırlar. Eserinde tarihin antitezini, tarihselin karşıtı bir belleğin inşasını sorgulatan Dido Sotiriyu, Yaşar Kemal gibi romanları aracılığıyla gayri resmi bir gerçekliğe yönelerek anı anlatımını devreye sokar.

Hatırlama kadar hatırlatma uğraşlarında yazarların mekânları uyarıcı olarak kullanırlar. Romanlarda birçok gelişme ve aşamayı hatırlatan anı(t) mekânların kullanıldığına erişilir (Young, 2016: 187). Dörtlemedeki sembolik ada, Kavlakzade Remzi tarafından yıktırılan kilise, I Nekri Perimenun'daki Pire limanı, Matomena Homata romanındaki amele taburları ve yeniden Pire, göçmen mahalleleri ve gettolar; karakterlere geçmiş- şimdi mukayesesi yaptıran özel toposlardır. Siyasal kırılma ve kopmalarla gelen sosyo-kültürel dönüşüm de bu anı(t) mekânlar sayesinde ölçülür. Toplulukların belleği bahsedilen mekanlardan bağımsız şekillenmez (Nora, 2006: 9). Bireysel ya da kolektif olarak bu yerlerde bir şeyler edinilir ama aynı zamanda bir şeyler de oralara bırakılır (Leys, 2000: 39). Gelmelerde veya gitmelerde bu yerler kişilerin bir şeyleri geri getirmelerini, hatırlamalarını mümkünleștirir. Roman kahramanlarının her biri yıllar sonra da olsa nice yaşantı ve hatırayı bunlar sayesinde anımsar. Şehir gibi ada da tüm sosyolojik farklılığına rağmen bir hatırla(t)ma mekânına dönüşür (Truc, 2012: 148-149). Mübadeleyi anı(t)laşan mekânlar üzerinden okuma yazarların müşterek bellek uğraşını ortaya koyduğu gibi, aynı örnek mekânlar kolektif/ sosyal hatırlamanın değişkenliğini de kapsar. Bahse konu olan bellek uğraşları geri gelmeyecek olmanın yarattığı ruh halinde ve buralarda biriktirilenlere bir daha dönülmeyeceğinde eşitlenir. Diğer bir anlatımla durum ve/veya olayların kişisel ya da kitlesel boyutu söz konusu anı(t) mekânlarda kalıcılaşır. Mekân, kapalı veya açık, hatırlama ve unutmada temel bir parametre olarak karşımıza çıkar. Başkaca söylersek bireysel, ailesel ve toplumsal çıkışsızlıklarda mekân; geri dönüşsüzlüğü ve bitişi anla(t)mak üzere öne çıkarılır.

Dido Sotiriyu'da, Yaşar Kemal'de olduğu gibi karmaşık olay örgülerine rastlamasak da, olumsuzun hatırlanışı ve bunun dile getirilişi bellek yaratımına biçim veren mekâna paralel gelişir. Siyasi karar ve olayların karşı konulmaz tesiri ile karşı karşıya kalan karakterler bulundukları ortamlardan bir şeyler aktarırlar. Toplumların sürüklendiği ancak aitlik hissedilmeyen yerler ya da "yeni yurtlar" dolayısıyla mekân, mübadelenin kurulumunda önemlidir. İki yazar da dönemlerinin koşulları içindeki insanı tüm boyutlarıyla ele alırken, bunu mekânsal unsurları da sosyal bir zemine yayarak yapmaya çalışır. Savaşlar öncesi Anadolu'daki yaşam ve paylaşımlar romanların ortak aktarımıdır. I Nekri Perimenun romanındaki ziyaretçilerden geçilmeyen Mağilerin eviyle Matomena Homata romanındaki Türk köylülerinin uğrağına dönüșen Aksiyotislerin evi; 
Karınca adalıların hanelerini tamamlayacak şekilde betimlenir. Çanakkale Savaşında yaralıların hayata döndürüldüğü kilise, adalıların toplandığı çınar meydanı ve Aliki'nin Müslüman işçilerin çocuklarıyla oynadığı sabun fabrikası hatırlananlara kesitler sunar.

Küçük Asya Felaketi ve Emperyalizmin Doğu Akdeniz Stratejisi ${ }^{8}$ şeklinde çevirebileceğimiz kitabında "çalkantılı bir dönemin kahramanları ve tanıkları göz önünde olmaktan vazgeçtiklerinde gerçeği yaymaya daha çok ihtiyaç duyarlar. Böylece ya anılarını yazmaya ya da onları anlatmaya koyulurlar. Bende olduğu gibi. Dökülen kan unutulur, kalan ise mürekkep olur" (Sotiriyu, 1975: 7-8)

ifadelerini kullanan yazar, yazma amacı kadar yazılarının karakterini de açıklamış olur. Burası hatırlamanın, dolayısıyla anıların belli bir zamana ve mekâna ihtiyaç duyduğunu ve belleklere bunlar sayesinde tutunduğunu ortaya koyar (Schacter, 2006: 116). Eserinde gerçek bir kişiyi ve onun tanıklığından geçen yaşananları kurgulamakla Yaşar Kemal'den belli noktalarda ayrlan Dido Sotiriyu, günce gibi tutulan bir defteri başka bir düzeye taşırken, Bir Ada Hikâyesi'nde sadece anılarak geçilen birçok noktayı derinleştirir. Manolis Aksiyotis'in maruz kaldıkları bir sınıfın sesi olarak romana kazandırılmış olur ve savaş yıllarıyla gelen felâket, bireyselden toplumsala açtığı gedikle aşamalı bir biçimde nakledilir. Bir Ada Hikâyesi'nde ise anı paylaşımı teknik bir boyutta karşımıza çıkar. Romanın, her karakterin geçmişini ortak alanda anlatmaya koyulması anı anlatımıyla desteklenirken, bunun Dido Sotiriyu'dan ayrı bir yazınsal işçilik örneği ortaya koyduğunu ifade etmek gerekir.

Yaşar Kemal'in Dido Sotiriyu'ya göre bir olaydan çok durumlara eğildiğini ve her durumun kişisel veya kolektif bir kırılmayı verdiğini söyleyebiliriz. Dido Sotiriyu romanlarından ayrı düşecek şekilde Bir Ada Hikâyesi'nde çok yönlü gidişlerle oluşan durumlar, bazen iç içe bazense birbirinden oldukça bağımsız bir biçimde gelişirler. Her iki yazarda, hatırlamayı ve hatırlatmayı kurgusal düzeneğe sabitleme yöntemlerinde farklılıklara rastlansa da, hatırlama bağlamının içinin doldurulmasında ortak başlıklara bir eğilimin olduğu tespit edilir. Yazarlar kartopu tekniğini andıran bütünleşme noktalarında askerlik, kaçakların yaşayışları, anaların perişanlığı gibi alt izlekler sunarken örneklemeci bir paralellik gösterirler. Her ne kadar Dido Sotiriyu romanlarında sonra, Yaşar Kemal'deki kadar kararlı olmasa da, bellek uğraşlarının önce ve sonrayı vermede birbirini tamamladığı gözlenir. Bir Ada Hikâyesi'ne oranla öncenin tüm çehreleriyle çizildiği Dido Sotiriyu romanlarında hatırlanan ve hatırlanacak olan bu önceyken, Yaşar Kemal'in dörtlüsünde her șeye rağmen bir sonra vardır ve

8 Emperyalizmin asla değişmeyeceğini, 1922 yılında İtilaf bloğunun ihanetinin sonraki yıllarda boyut değiştirerek NATO odaklı sürdüğüne ve siyasal düşüncelerini içeren kitabıdır. Burada bahsettiği insanlık dramına götüren aktörlere ve kullandıkları araçlara, romanlarında doğrudan yer vermese de bu kitapta kişisel düşünce ve değerlendirmelerine ulaşılmaktadır. Bu noktada eser kurgulamak istediklerinin gerçek boyutuyla olaylardan mesul tuttuklarını vermesi bakımından önem teşkil etmektedir. 
bu sonrada hatırlananlar mübadele öncesi olumlu yaşamı aratmaz. Diğer bir ifadeyle dörtlemeye sonranın sağlayacağı onarımla başlayan Yaşar Kemal, yeni hayatın inşasında nelerin olacağını nedenleriyle açıklarken, Dido Sotiriyu'nun romanlarında bu gayretin olduğunu söylemek güçtür.

Örüntü bakımından oldukça dağınık yazılan Berdemeno Kuvari ve Enomena Valkania kitaplarının içeriğinin neredeyse tamamını bulduğumuz Matomena Homata romanında da, Almanya'nın siyaseti kadar azınlıklara dönük algı yönetiminin kısa sürede karşılık bulmaya başladığı görülür. Aksiyotis, Anadolu'daki gayrimüslim azınlığın bilhassa Almanya tarafından tehdit olarak algılandığına ve bu nüfusun ekonomik olarak etkisiz hale getirilmek istendiğine doğrudan değinir. Yine de propagandayı körükleyenlerin emellerine ulaşamadıklarını, iki halkı karşı karşıya getirmenin sanıldığı kadar kolay olmadığını şöyle sürdürür:

Gerçekten ögrrenmek istediğim tek bir șey vardı. Lozan'da bir masa etrafinda toplanan yirmi ila otuz kişi Türkler ve Yunanlılar için bu dönüsssüz kararın ne demek olduğunu biliyor muydu ve böyle bir karar, bu kadar kolay mı alınıyordu? (Aksiyotis, 2016: 279).

Romanın omurgasını bu bakışla kuran Dido Sotiriyu, mübadelenin çok öncesinde ikili ilişkiler arasına nifaklar sokulmaya uğraşıldığına yer verirken; birbirinde konaklayan, dar günde birbirine koşan iki toplumun ve hatırladıklarının değiş(e)meyeceğinde diretir.

Bir Ada Hikâyesi'nde karakterlerin mübadele köklü büyümelerini, Dido Sotiriyu'da ise mübadele şartlarında büyüyen karakterler görürüz. Buna savaş vurgunu Vasili'nin gerek ruhsal gerekse fiziksel büyümesini örnek olarak verebiliriz. İstanbul doğumlu ve Karıncalı Atoynatanoğlu'nun sosyal özgüvensizliğinin sebebi bellek altında biriken Balkan Harbi, Çanakkale, Sarıkamış, Dumlupınar savaşları ve Amele Taburları'nda yaşananlar olsa da sürülmek; karakter için ayrı bir yerde duran bir anlaşılamayandır. Romanda Atoynatoğlu'nun mübadelenin çok öncesinde hastalandığına eriștiğimiz kesit, adaya sağ dönene değin yaşadıklarını özetler mahiyettedir.

Ben çok öldürülmüş insan gördüm, ben çok kopmuş kol bacak, paramparça edilmiş, kan içinde bedenler, köpek sürülerinin paylaşmak için birbirlerini parçaladıkları insan ölülerini gördüm. Ben, donmuş, kaskatı kesilmiş, dimdik, gözleri yumruk gibi dışarıya uğramıs ölüler gördüm. Iniltilerini duydum, yüzlerce insanı... Bu iniltilerin birdenbire kesildiklerini de... Sonra hepsinin gözlerinin pörtlediğini (Kemal,2016: 101).

Atoynatoğlu'nun, savaş meydanlarında gördükleri, omzunda taşımak zorunda kaldığı ölüler ve yüzbaşının kurşun sıkmaya dönük komutları zihnini alıkoymuştur. Öyle ki bir noktadan sonra yaşananların tek bir savaşta meydana geldiği düşünülmeye başlanır. Güç bela hayatta kaldıktan sonra -ki burası adadır- belleğinde parça parça geri getirdikleri savaş karşıtlığını savunacak şekilde tasarlanır. Ne var ki savaşla birlikte ortaya çıkan orantısız ruhsal ve fiziksel şiddetin etkilerinin, karakterin dünyaya 
geldiği yer olan Mirmingi'de güvenli yaşama rağmen sürdüğü dikkatlerden kaçmaz. Kimsesiz kalan karakterin savaş sonrası kendini güvende hissedebileceği yaşam ve alışkanlıklar alanındaki huzursuzluğunu negatif tecrübelerinden bağımsız okumak zordur. Savaş çoktan son bulmuş olsa da, roman kahramanının zihni düzlemde savaş alanında bulunduğu ortadadır. Mübadele de iyiden iyiye sürüklendiği bir çıkmaz olarak karşısındadır. Henüz savaş travmasının benliğinde sürdüğü Vasili için sürgün yeni bir meçhuldür. Yaralı belleğine karşın kanunu aşmak anlamına gelen sivil itaatsizliğe geçecek ve Yunanistan gerçeğine kendi sınırlarını kapatacaktır. Aitliğini ve kimliğini taraf kalarak korumaya çalıșmakla, karşılaştığı istenmedik durumu bertaraf etmeyi seçecektir. Bu noktada bireysel mücadelesi, her şeyden önce yabancı bir yere dâhil olmak istemediğini ve gitmekle orada yabancı konumuna düşeceğini bilen bellekte gerçekleşir. Karşısına bir koşul olarak konulan Yunanistan'dan yana ol(a)mayacağı bu bellekle açıklanır. Roman da bahse konu edilen bu belleğe ve belleğe kazınanlara içkin bir biçimde şekillenir. Adalıların "Yunanistan bizi ne yapacakmış?" siteminin içinde zamanla isyana dönüştüğü Vasili için Yunanistan, Anadolu yurdu değildir. Orada yaşayanların Anadolu'yu ve insanını anlaması, sahiplenmesi ve onlarla birlikte yaşaması durumu söz konusu olamaz. Anadolu hatırasının yaşadığı Karınca'yı ve Karıncalıyı özümseme bu yeni koşullar altında bulunmamaktadır. Roman kahramanının ada topluluğunu takip etmemesi ve onlardan kopması bu farkındalığa dayandirilır.

Benzer bir süreci yaşamak zorunda bırakılan Girit mübadili Ağaefendi Musa Kazım'ın da Vasili'ye benzer bir biçimde, kendi bireysel faciası içinde Türkiye gerçeğine hazır olmadığı ve bunu yaşamsal düzeyde reddettiği görülür. İstanbul'da eğitim görmüş olması ve ayrıca şehrin güzelliğinin hiç değişmemiş olması da, onun burada yaşaması için yeterli gerekçeleri oluşturmaz. Öğrencilik yıllarından, dostlarından ve Türkiye insanından sitayiş ve özlemle bahsetse de buraya dönmemek üzere yerleşmek durumu başkadır. Bu bağlamda iki karakterin de güvensizlik bunalımı içinde anlaşılır noktalara atıflarda bulunduğuna erişilir. Sınırın bir ucunda kalmak için direnen Atoynatanoğlu için belirsizlik neyse bu sınırda yetişen Musa Kazım özelinde sınırın ötesi de odur. Anlaşılacağı üzere savaşlardan sonra mecburi bir şekilde ortaya çıkan karşılıklı değiş- tokuş Türkiye insanı için de Yunanistan insanı için de bir yıkımdır. Nitekim böylesi bir değiş-tokuş, bireylerin ve akabinde toplumların karşısına çıkarılan süresiz bir yolculuktan çok daha fazlasıdır.

Girit ile benzeşen Mirmingi ve onun mezarlıklarını andıran ada mezarlığı karakteri geçmişe ve atalarına götürür. Her ne kadar kaybedilenin bir benzeriyle karşılaşılsa da, yitirileni yeni olandan ayıran onun yaşanmışlığı ve anısal olmasıdır. Roman kahramanı, anılar yoluyla geçmişi ve at yetiştirdiği günleri yâd ettiğinde çiftliğine gözü gibi baktığına emin olduğu Niko'yu hatırlar. Onun da İsmail gibi dövülmüş, hırpalanmış olabileceğini düşünür. Nitekim sık sık “Bizim Girit'teki çiftlikte kalan Niko ne 
yapıyor," diye sorar. Kavlakzade Remzi ve adamlarının İsmail'e yaptıklarını aklına getirmesiyle tereddüdünün de artığı anlaşılır. Kendini ve Elia Efendi'yi kötülüklerden sakınmak istediği gibi bu iki kâhyayı da aynı hassasiyetle korumak istediği tespit edilir. Bunu destekleyen bellek altı mesajı da her anlamda manidardır. Türkiye'de yaşananların benzerlerinin Yunanistan'da yaşandığını/yaşanabileceğini; her yerde zalimlerin, gaddarların, kana susamışların olduğuyla açar: "Orada Nikoya Türk tohumu diyerek gözlerini oyacaklar yok mu?”(Kemal, 2020: 55).

Eş bir izlek, balıkçı Hıristo'nun hikâyesinde açığa çıkar. Yunanistan'a gitmemek için ailesiyle perili köşke saklanan karakter Vasili gibi jandarmaları atlatmayı başarır. Bireysel belleğinde yer edenler, diğer mübadil karakterlerle örüntü içerisindedir. Hıristo'nun da anasının ona sık sık tekrar ettiği, "baban diyordu ki Yunanlılar Rumları hiç sevmezler" (Kemal, 2020: 207) sözü gitmemesi için yeterli bir inanç olarak öne sürülür. Önceki kuşağın düşünce ve yönlendirmelerinin ne derece etkin olduğunu gösteren bu pasaj, oğulun hatırlamasında geçmişin belirleyiciliğini verir. Vaktiyle İsmail'in yanında topçu olması ona her defasında anasının dediğini, "kimsesiz ve öksüz olmadıklarını" hatırlatır. Nitekim Yunanistan ihtimalini yerellikle aşmayı deneyen balıkçı, babasının türküsünü tutturur. Jandarma olan Rum Hıdır'ın oğlunun Yunan'da veya Yunan'la bir işinin olmadığını/olamayacağını okuduğumuz bölümde, kalmak; buralı olmakla, Anadolulu olmakla açıklanır. Hıristo'nun "bu toprak bizim" (Kemal, 2020: 217) ifadesi esasen gidilecek bir yerin olmadığını ortaya koyar.

Yaşar Kemal'de savaşlar sonrasının hususi hattı şeklinde öne çekilen mübadelenin bir kâbus gibi adaya çökmesi bir noktadan itibaren daralmaya uğrar. Bu da anlatıcının süreci karakterlerin dışında açmayacağını ve onlarda bıraktığı etki üzerinden genişleteceğini gösterir. Karınca'ya ikinci gelişiyle gündelik hayatı durduran yüzbaşıyı dinleyen kırgın kalabalığın daralma göstermesi ve hikâyenin dörtlü boyunca Vasili, Lena ve Musa Kazım Ağaefendi etrafında boyutlanması ile kalıcı göç dayatması temelinde insanlık gerçeğine hacim kazandırmak istenir. Burada hatırlamanın ötekine ihtiyaç duyduğu ilkesi yeniden belirir. Her birinin çıkışsızlığı kısmen de olsa bir diğerinin tanıklığına başvurmakla kırılır. Başka bir ifadeyle mübadeleye tabi tutulan nüfusun anlatıları, savaşlardan bir şekilde geri dönenlerin anlatılarıyla kesişir. Dido Sotiriyu romanlarında sürülmenin tanım ve anlatımı karakterlerin büyümelerini bastırır. Savaşla evlerinin bir sığınağa dönüştüğü Mağilerde toplaşan kalabalıktaki Kona Angeliko'nun kızı Asimina'nın tanıklığını andıran birkaç anlatının dışında buralarda bir derinleşme görülmez. Bir Ada Hikâyesi'ndeki kitlesel yası tek tek karakterlerde görsek de, Dido Sotiriyu'da dörtlüde olduğu gibi yas halinin büyüttüğü karakterler bulmayız.

Yaşar Kemal'in ana karakterlerinde görülen duygudaşlık durumunun da Dido Sotiriyu romanlarına kıyasla farklı geliştiği gözlemlenir. Oysa Poyraz Musa daha en başından mübadilleri anlayacak bir dertli olarak 
düşünülür. Savaşlar sonrası hayatı, Emir'in korumak üzere kaçırdığı ailesini ve köyünü aramakla geçer. Sürgünü önceki kuşaklardan epeyce dinlemiş karakter için Karınca'dakilerin kendisine anlattıkları uzak değildir. Suça bulaşmamışsa da Yezidi kıyımında gördükleri belleğinden bir türlü silinmez ve her göçmen veya mübadilde tepkisiz kaldığı bu kıyımdan, Kafkasya'dan, dağlarından ve yakınlarından bir şeyler bulur. Üzeyir Han'a söyledikleriyle sürgünü bir noktada kanıksadığı görülür. "Ne yapalım, biz Çerkes milleti, sizin gibi Hanlar da bizim gibi köleler de bütün dünyaya sürüldük, dağıtıldık, perişan edildik" (Kemal, 2016: 37). Dido Sotiriyu'da ise hatırlama ve hatırlatmaya verilen önceliğin karakterler arası duygudaşlık kurulmasına bir noktadan sonra engel olduğuyla karşılaşılır. Bunu öznelerin birbiriyle paylaşımlarında menfi duygusal yükün sürekli öne çekilmesiyle açıklamak mümkündür. Öte yandan Poyraz Musa'nın, kıyıma şahit olan Şerife Hatun'un tanık olduklarını dinleyene kadar tam anlamıyla yaşadıklarından arınamaması, Ağaefendi Musa Kazım'ın kendisini ve hikâyesini Elia Efendi'de görmesi, İsmail ve Niko arasında kurulan benzerlik onları yas durumunda buluşturur. Durumu "başkasının acısını anlayabilme" ile açıklayan Akyıldız, (2018:160) bu tür ilişki ve yakınlıkların ötekiliği bertaraf etme maksadıyla düşünüldügünü söyler.

Yaşar Kemal sistemsel kusur ve aksaklıkları mübadelenin çok öncesinden başlatır. Savaşlarla imtihan edilen Anadolu'nun yönetim mekanizmasıyla da sorunlar yaşadığını gözler önüne sererken, savaşın neden olduğu ağır zayiat ve yıkımın menfaatçi, açıkgöz ve sahtekâr insanlar yarattığına da vurgu yapar. Bu da toplumsal hayata doğrudan etki eden önemli bir parametre olarak verilir. Mübadillerin evlerini açık artırmaya çıkartması, satış kağıtlarının prosedür gereği asılması, mülk satışına dair duyurunun hemen indirilmesi, kapalı kapılar ardında yapılan görüşmeler ve nicesi dönemin panoramasını verir. Anlatıcı, toplumsal faciaların yanında nizam eksikliğini, denetimsizliği ve bürokrasiyi hedef alır. Gelinen durumu içler acısı bir gerçeklikle betimlerken yer yer mizaha, yer yer ise kinayeye başvurarak Osmanlı'yı ve kurumlarını tenkit eder. Osmanlı eskiyi ve eskide işlenen hataları temsil ederken yeni devlet sürekliliği ve kusursuzluğuyla ayrı tutulur. Cihana örnek olma durumu bu devletin en mühim özelliği olarak çizilir. Esasen Türkiye toplumunun maruz kaldığı politik karar ve krizler yenisi ile telafi edilmek istenir, hatırlanacaklar da buna uygun şekilde dönüştürülür.

Öte yandan Bir Ada Hikâyesi'ne kıyasla Hıristiyan erlerin askerlik hizmeti için girdiği özel çalışma birliklerine daha geniş yer veren Dido Sotiriyu, Matomena Homata romanının ikinci ana bölümünü buradaki yaşayış ve işleyiş̧e ayırır. Hikâyeyi gerçekten yaşamış olan Manolis Aksiyotis'in doğrudan bu yerde bulunmuş olması, romanda da bu mekânlara ve buradaki deneyimlere daha fazla ağırlık verilmiş olabileceğini düşündürür. İ Nekri Perimenun romanında birkaç cümleyle vurgulanarak geçilen bu yerler hakkında tanık Aksiyotis, buraların insanlar için tasarlanmış olamayacağından bahseder: 
Az ötede saman ve çuvalların orada toprak yarı metre yüksekti. Her askerin yatağı bunlardı. İçeri girdiğin gibi miden bulanırdı. Ağır hasta olanlar ayakta zor duruyor, istifra ediyordu. Terin o ekși kokusuyla karışlyor, hasta nefesi çatının çürük dallarıyla küf yayıyordu. Milyonlarca bit kıyafetlere tırmanıyor, saçlara, enselere, pireler kulaklara ve bedene, deriye işliyor onu yüzüyor, kana buluyordu. Inleyişler, söylenişler, horlamalar karanlıkta asabı iyiden iyiye bozuyordu (Aksiyotis, 2016: 133).

Henüz mübadele kararlaştırılmasa da Aksiyotis'in bilinçaltı çoktan ölü saklayıcılar ve ölü taşıyıcılarıyla doludur. Tüm bu orantısız kötülük, öncesinde de belirtildiği gibi emperyalistlerden bilinir. Aksiyotis, dostlarını her kaybedişinde emperyalistlerin kazandığını, hiçbir şeye doyamamış gençlerin, bu haksız gidişlerinin ancak emperyalistlere ve onların tasarılarına yaradığını; sermayeyi elinde bulundurmak isteyenler böylesi doyumsuz oldukça daha çok ölünün verileceğini yazar. Veda etmek durumunda kaldığı ve asla unutamayacağı her yüz ve hatıra ise ona üstleri, patronları, şirketleri ve kazancı çağrıştırır. Bireysel olanlar kadar toplumsal trajedilerin de yine buna bağlı olarak şekillendiğini, ölenlerin sadece birer rakamdan ibaret olduğunu açımlar. Kendi izlenimleri ve maruz kaldıkları aracılığı ile, çıkar ve ikbal uğruna hiçbir şeyi esirgemeyecek odaklara ve onların yönlendiricilerine işaret eder. Aksiyotis'in bireysel savaşımının da emperyalizm ile olduğu anlaşılır. Anadolu savunmasında ve daha sonra gönüllü olarak katıldığı Yunan Ordusunda da onun bireysel savaşı daima emperyalizme karşıdır. Yazdıklarından, savaşın uluslararası ilişkiler bağlamında realist bir mantıkla ilerlediği ve gerçek mesullerin böl-yönet taktiğiyle ikili münasebetlere acımasızca yön verdiği, çizilen rotanın bir arada tutmaya değil ayrıştırmaya ve bir karşı taraf, bir "öteki” yaratmaya dönük olarak tasarlandığı okunur.

Dido Sotiriyu tanığın hatırlama tümseğini, Manolis Aksiyotis'in canlı belleği ve kendi öz yaşamına yaptığı vurgularla örer. Tanıkla kurduğu içsel bağ ve deneyime yabancı olmayışı belleklerini düğümlerken ikinci çaba, yazarın okura attığı düğümde görülür. Burada mühim olan bilişsel kaydın kurgusal hakikat üzerindeki payı değil, kurgusal hakikatin bilişsel bir kaydı geri getirişidir. Organik bir ilişkinin olmadığı geçmişi başka bir zaman ve boyutta kazandıran roman, hatırlamanın değişkenliği üzerine birçok veri sunar. Otobiyografik hatırlamanın görülmediği Bir Ada Hikâyesi'nde seyreden hatırla(t)manın tamamen kurgusallığa dayanması onu başka bir anlatı düzlemine taşır. İki yazarın bellek uğraşı kıyaslamasında da en temel ayrılık buradan gelir. Diğer bir ifadeyle duygusal içerimlere kurguyla dikkat çekilen Yaşar Kemal'in dörtlüsü ile canlı bir bellek aktarımıyla kaleme alınan Dido Sotiriyu'nun Matomena Homata ve çocukluk travmasına bina edilen $\dot{I}$ Nekri Perimenun romanları ayrı anı ve anıştırma öbeklerine sahiplerdir. Yaşar Kemal'in "insanlar yerlerinden yurtlarından, ülkelerinden edilip sürgüne gönderiliyorlar, bir daha dönmemek üzere. Bu romana çalışırken mübadeleyi inceledim" (Kemal, 2009: 257) ifadesi iki yazarın uğraşını da özetler. 
Bir Ada Hikâyesi'ne döndügüumüzde mayıs ayının 10'una kadar hazırlanmaları için mühlet tanınan kalabalığın hemen eski yaşayışlarına dönmeleri, gündelik işlerini aksatmamaları ve ritüelleşen balık ve kuş şölenlerine devam etmeleri mübadele kararını tanımama hatta inkârla açımlanırken, Dido Sotiriyu'nun iki romanında da inisiyatif alacak karakterlere rastlanmaz. Manolis Aksiyotis, Nikitas Drossakis ve Vasilis Mağis gibi süreci dönüştürmek için hamlelerde bulunan karakterlere rağmen Dido Sotiriyu'nun romanlarında dörtlüde gördüğümüz örgütlü seferberliği bulmayız. $\mathrm{Bu}$ anlamda Yaşar Kemal adaya geldikten sonra yoğunlaşarak sorunların üstesinden gelen bir kitle tasarlar. Böylece hatırlananlar tüm yıkıcılıklarına karşın olumlanır. Bir Ada Hikâyesi'nde savaş veya mübadeleyle dikkat çeken yer değiştirme deneyimlerinin her şekilde yaralı geri getirmeleri onardığı açıktır. Karınca Adası da arındırma ve iyileştirme işlevini böylelikle tamamlamış olur. Buradan bakıldığında Dido Sotiriyu romanlarında benzeri bir dönüştürücü fonksiyona sahip mekânlardan bahsetmek güçtür.

Karınca, hiç boş kalmayacak bir yer olarak kurgulansa da yabancı göçmen ve mübadil topluluk için bu ada tüm olanak ve verimliliğine rağmen gelinen yerleri, bırakılan yurtları tam anlamıyla karşılamaz. Adada ısrarla kurulmaya çalışılan kolektif yaşama karşın geride bırakılanlar her firsatta hatırlanır. Öyle ki yeni hayatın inşası ancak bu hatırlama ve hatıraların gündeme gelmesi/getirilmesi ile mümkün hale gelir. Öte yandan burası Anadolu'nun hâlâ ayakta olduğunun, suların durulmadığının öğrenildiği ve sığınmak üzere son imkân olarak sunulan yerdir. Bütün Anadolu'nun çalkalandığı tekrarlanırken Karınca'nın bir toplanma alanı olacağı açıklanır. Bu toplanma alanı da kültürlenmenin ilk durağı olarak betimlenir. Ağaefendi ve kızlarından Lena Ana gibi, her bir karakterin bir yaşanmışlık ve kültürel gerçeklik ile orada bulunması ya da adada buluşması topluluğu dönüştürür. Gündelik ihtiyaçlar gibi aslında çok basit konular bile yetişme tarzını, sosyal algıyı, kopup gelinen yerleri ve nicesini hissettirir. Bu noktada Yaşar Kemal, Dido Sotiriyu'ya göre daha ılımlı, daha aşılabilir bir kültürel boşluk ve yadırgama çizerken, Sotiriyu kültürel bocalamayı daha keskin hatlarla verir:

Karşı, Küçük Asya kıyılarında, ışılklar yanıp sönmekte, gözler yanıp sönmekte. Karşı, evler biraktık, kilit vurulu sermayeler, ikonostasta ${ }^{9}$ taçlar, mezarlıklarda ataları. Çocuklar, aileler, kardeşler bıraktık. Mezarsız ölüler. Orada. Karşı, orası düne kadar yurdumuzdu! (Sotiriyu, 2017: 384).

\section{Sonuç}

Karşılaştırmalı bir şekilde iki yazarın mübadele kurgusunu ve bellek uğraşını tespit etmeye gayret ettiğimiz çalışma, bizi romanın sosyolojik anlamda özgül bir araştırma sahası ve toplumsal gelişmeler bağlamında da inşacı bir tür olduğu yaklaşımına götürmüştür. Çalışma romanın hatırla(t)mada bir temsil, dolayısıyla yeni bir doğa kurabileceğini

\footnotetext{
${ }^{9}$ Ortodoks evlerinde ikonaların muhafaza edildiği yer.
} 
göstermiştir. Romanlarda seçilmiş bir olay üzerinden kurgunun nasıl dokunduğuna baksak da, dokunanların her bakımdan yaşanılandan ya da ana doğadan başkalaştığı saptanmıştır. Kurmacanın kayda geçmiş, tarihsel bir gerçekliği yoğurarak, kayda geçmemiş ve sürekli yenilenebilen sosyal/toplumsal gerçekliğe taşınması süreci izlenmiş, tarihin veya egemen söylemin artzamanlı düzleminden romanın kurgusal düzlemine geçişi ölçülmüştür.

Türk- Yunan Nüfus Mübadelesi sinemadan edebiyata farklı yöntem ve araçlarla sosyal dolaşıma sokulmuştur. Anadolu doğumlu Rum yazarlar için Yunanistan'a göç, Türk- Yunan Nüfus Mübadelesinin oldukça öncesinde İzmir Olayları'yla başlasa da Türk romanında mübadelenin işlenmesi doksanlı yılları bulmuştur. Romanlar da gerek Türk gerekse Yunan edebiyatında zorunlu göçün toplumsal algıyı ne şekilde biçimlendirdiğini yansitan araçlara dönüşmüştür.

İnsanlık tarihinde savaş, orantısız şiddet, programlı imha gibi kırılmalar daima entelektüellerin dikkatini çekmiştir. Olağanüstü deneyimlerin ardından hayatta kalanların günlükleri, otobiyografileri ve anıları yaşananlara içkin bir bellek bıraktıkları için ilgi uyandırmıştır. Tarihsel anlatının dışına çıkma yönelimi canlı kayıtları, görselleri sistematik biçimde açıklamayı beraberinde getirmiştir. Bunun için hadiselere birebir tanık olmuş kişilere ulaşılmış, bunun mümkün olmadığı durumlarda da o kişilerin yakınlarıyla görüşülmüştür. $\mathrm{Bu}$ çalışma romanın hatırla(t)ma eksenli incelenebileceği gibi flaş olay ve anıları geri getirebileceğini tartışmaya açmıştır. Romanın duyusal, kültürel, mekânsal ve tarihi olguları canlandırma yoluyla yeni bir oluşa taşıyabileceğini ve yitmiş bir zamanı kurtarabileceğini uygulamalı şekilde açıklamaya çalışmıştır. Diğer bir deyişle bu çalışma, türü kendine özgü anlatısal ve aktarımsal teknikleriyle bir hatırla(t)ma aracı olarak değerlendirmenin mümkün olduğunu ileri sürmüştür. Manolis Aksiyotis gibi pek çok tanığın ve anlatılarının roman türüne kaynaklık edebileceğini; bu anlamda romanın mühim bir inceleme sahası oluşturduğunu savunmuştur.

Çalışmada Bir Ada Hikâyesi, İ Nekri Perimenun ve Matomena Homata romanlarına Türk- Yunan Nüfus Mübadelesi üzerinden bakılmış, böylece iki yazarın hatırlatma yörüngeleri ölçülmüştür. Yaşar Kemal Bir Ada Hikâyesi'nde diğer romanlarından oldukça farklı bir göç türünü; TürkYunan Nüfus Mübadelesini işlemiş, iki uluslararası aktörün bu zorunlu tahliyelerle dönüşen ilişkilerine eğilmiştir. Kemal, dört ciltlik eseri boyunca travmatik deneyim, negatif anı, sosyal depresyon gibi olguları yansıtmış; yerleşilmeye mecbur bırakılan yeni yaşam ve yurtları kültür- kültürlenme, kabul- inkâr, entegrasyon-yabancılaşma üzerinden okumuştur. Bu açı romanlarını konvansiyonel göçe dayandıran iki yazarın kurgusal kesişim ve bellek aktarımlarını takip etmemize, romanlarda öne çıkan göçle doğrudan veya dolaylı şekilde ilinti gösteren unsurları çıkarmamıza olanak tanımıştır. Her iki yazar için de göç her ne kadar kurucu etken olarak kalsa da, göçün 
kurgulanışının Yaşar Kemal'e kıyasla Dido Sotiriyu'da dış politika yöntemleri ve araçlarıyla desteklendiği görülmüştür. Dido Sotiriyu'nun iki romanında göç modeli daraltılmış bir şekilde Türk-Yunan Nüfus Mübadelesi'yle kalırken, Yaşar Kemal mübadele kadar derinleşmese de mübadele dışı göçlere de yer vermiştir.

Yaşar Kemal'in dörtlüsünde bireysel yaşantı ve deneyimler kadar karakterler arası bir kurgu öne çıkarken, aynı kurgudan Sotiriyu'nun karakterleri için bahsetmek güçtür. Dido Sotiriyu faciaları açarken, Aydın ve İzmir'den zorunlu çıkışı siyasal kararlar ve kesinlikler üzerinden geliştirirken, Yaşar Kemal bunu bellek altı, duygudaşlık ve duygulanımlar üzerinden yapar. Başka bir ifadeyle Sotiriyu'ya göre Yaşar Kemal'in karakterleri kayıplar ve yas durumlarında daha sahiplenicidirler. Bireysel, ailesel ve toplumsal facialarda daha yalıtılmış bir görüntü veren Dido Sotiriyu, Yaşar Kemal'e klyasla politiktir. Yaşar Kemal'in değişmeceli adasında politize olmuş kimse yoktur, böyle birine ihtiyaç da duyulmaz. Faciaları örmede dahi siyasal boyut minimalize edilir, neredeyse yok olur. Dido Sotiriyu için siyasiler ve izledikleri siyaset, faciaların ana sorumluları olarak görüldükleri için etkileri hafife alınmaz. Karınca Adası her ne kadar yerleşilecek tek alternatif olarak sunulsa da, savaşlar ve göçlerin neden olduğu yıkımların onarılacağı yegâne yer olarak belirlenir. Bu bakış açısı Sotiriyu'nun iki romanında da yoktur. Sotiriyu'da karakterleri iyileștirme, onlara yaşamsal alanlar kurma gibi bir girişim söz konusu değildir. $\mathrm{Bu}$ bağlamda Yaşar Kemal, okuru daha en başından adadan gidememenin, adaya yeniden dönmenin ve burada kalmanın esaslarını verir.

Yaşar Kemal sermayenin el değiștirmesini mübadele ile bağlantılarken, Dido Sotiriyu mübadillerin Yunanistan'ın ekonomik büyümesine katkıda bulunduklarına yoğunlaşır. Her mübadilin mensubu olduğu çevreden ve en önemlisi Anadolu'dan bir şeyler götürmesi bilhassa $\dot{I}$ Nekri Perimenun'un temel izleğidir. Başka bir ifadeyle yazar eseriyle, Yunanistan'ın daha limanda dışladığı nüfusun zamanla kalkınmasında yapıcı rol oynadığını verir. Yaşar Kemal Yunanlıların ırkçı çıkışlarını bir bellek mekânına dönüșen Pire ile sınırlı tutarken, Dido Sotiriyu bu noktayı genişletir ve yeni yerleşimlerle mübadillerin Anadolu'yu kültürel anlamda taşıdıklarını açar. Farklı yaş grupları ve cinsiyetlerin koparılan yerleri yaşatma gayretlerine müstakil surette değinen Dido Sotiriyu, vaktiyle istenmeyen "Türk tohumlarının" hizmetlerini sıralamaya koyulur. Yaşar Kemal ise mübadillerin servetlerinin gidenler için nasıl bir son oluşturduğu ve kalanlara nasıl bir hayat bağışladığı üzerine düşünür.

Berdemeno Kuvari ve Enomena Valkania kitaplarını bütünleşik şekilde okuduğumuz Ĕgo, O Manolis Aksiyotis başlıklı otobiyografinin, Matomena Homata romanına birinci dereceden kaynaklık ettiği saptanmıştır. Bir liman işçisinin tanıklığı sonucu oluşturduğu kendi metninden, tıpkı savaşların ortaya çıkma nedenlerinde olduğu gibi, Türk- Yunan Nüfus Mübadelesi'nin gerçekleştirilmesinin ve Türkiye-Yunanistan ilişkilerinin aralıklarla 
tırmanmasının sorumlularının emperyalist güçlerin olduğu okunmuştur. Mübadil Manoli Aksiyotis gibi Dido Sotiriyu da zorunlu tahliyenin Avrupa köklü olduğunu ileri sürmüş ve bu hat onları Yaşar Kemal ile buluşturmuştur. Her iki yazarın eserlerinden de mübadele olayının söylenenlerden çok söylen(e)meyenlerde hacimlendiği sonucuna ulaşılmış, yazarların Anadolu'ya ve Anadolu insanına karşı duydukları içsel sorumluluğun yüzleșememe ve inkâr zincirini kırmada kesiştiği tespit edilmiştir.

\section{KAYNAKÇA}

Akgün, A. - Kumsar, İ. (2018). Mübadil Türklerin romanı. Ankara: Gece Kitaplı̆̆ı. Aksiyotis, M. (2016). Ĕgo, o Manolis Aksiyotis. Atina: Balta.

Arı, K. (2017). Türk roman ve öyküsünde mübadele. Tarih ve Günce, 1/1, 5-28.

Akyıldız, H. B. (2018). Mübadele romanlarında kimlik ve ulusçuluk. İstanbul: Doğu Kütüphanesi.

Assmann, J. (2015). Kültürel bellek. Eski yüksek kültürlerde yazı, hatırlama ve politik kimlik. (Çev: Ayșe Tekin), İstanbul: Ayrıntı.

Barnier, A. - Sutton, J. (2008). From individual to collective memory: theoretical and empirical perspectives. Memory, 16 (3), 177-182.

Boyer, P. - Wertsch, J. V. (2015). Zihinde ve kültürde bellek. İstanbul: Türkiye İş Bankasi.

Bozdağlıoğlu, Y. (2014). Türk- Yunan mübadelesi ve sonuçları. Türkiye Sosyal Araştırmalar Dergisi, Yıl 18, özel Sayı 3, Ocak/January.

Connerton, P. (2014). Toplumlar nasıl anımsar. (Çev.: Alaaddin Şenel), İstanbul: Ayrinti.

Creet, J. - Kitzmann, A. (2011). Memory and migration. University of Toronto.

Halbwachs, M. (2018). Kolektif bellek. (Çev.: Zuhal Karagöz), İstanbul: Pinhan.

Kemal, Y. (2009). Binbir çiçekli bahçe. İstanbul: Yapı Kredi.

Kemal, Y. (2016). Bir ada hikâyesi -1. İstanbul: Yapı Kredi.

Kemal, Y. (2019). Zulmün artsın. İstanbul: Yapı Kredi.

Kemal, Y. (2020). Bir ada hikâyesi-2. İstanbul: Yapı Kredi.

Kemal, Y. (2020). Bir ada hikâyesi-3. İstanbul: Yapı Kredi.

Kemal, Y. (2020). Bir ada hikâyesi-4. İstanbul: Yapı Kredi.

Komisyon (1988). Türkçe sözlük. Ankara: Türk Dil Kurumu.

LaCapra, D. (1998). History and memory after Auschwitz. New York: Cornell University.

Leys, R. (2000). Trauma: A genealogy. London: University of Chicago.

Milas, H. (2000). Türk romanı ve öteki: Ulusal kimlikte Yunan imajı. İstanbul: Sabancı Üniversitesi.

Milas, H. (2005). Türk ve Yunan romanlarında "öteki" ve kimlik. İstanbul: İletişim.

Millas, H. (2005). Türk ve Yunan Edebiyatında Mübadele Benzerlikler ve Farklar. Yeniden Kurulan Yaşamlar 1923 Türk- Yunan Nüfus Mübadelesi, (Der.: Müfide Pekin), İstanbul: Bilgi Üniversitesi. 
Nora, P. (2006). Hafiza mekanları. Ankara: Dost.

Ricoeur, P. (2017). Hafiza, tarih, unutuş. (Çev.: M. Emin Özcan), İstanbul: Metis.

Rothberg, M. (2009). Multidirectional memory. California: Stanford University.

Schacter, D. (2006). The seven sins of memory: How the mind forgets and remembers. Boston: Houghton Mifflin, 2002.

Sotiriyu, D. (1975). I mikrasiatiki katastrofi ke i stratiğiki tu imperialismu stin mesoğio. Atina: Kedros.

Sotiriyu, D. (2017). I nekri perimenun. Atina: Kedros.

Sotiriyu, D. (2017). Matomena homata. Atina: Kedros.

Truc, G. (2012). Memory of places and places of memory: For a Halbwachsian socioetnography of collective memory. International Social Science Journal, 62 (201-202), 147-159.

Wegner, D. - Raymond, P. - Erber, R. (1991). Transactive memory in close relationships. Journal of Personality and Social Psychology, 61 (6), 923-929.

İyi Yayın Üzerine Kılavuzlar ve Yayın Etiği Komitesi'nin (COPE) Davranış Kuralları" çerçevesinde aşağıdaki beyanlara yer verilmistir. / The following statements are included within the framework of "Guidelines on Good Publication and the Code of Conduct of the Publication Ethics Committee (COPE)":

İzinler ve Etik Kurul Belgesi/Permissions and Ethics Committee Certificate: Makale konusu ve kapsamı etik kurul onay belgesi gerektirmemektedir. / The subject and scope of the article do not require an ethics committee approval.

Çıkar Çatışması Beyanı/Declaration of Conflicting Interests: Bu makalenin araștırması, yazarlığı veya yayınlanmasıyla ilgili olarak yazarların potansiyel bir çıkar çatışması yoktur. / There is no potential conflict of interest for the authors regarding the research, authorship or publication of this article.

Yazarın Notu/Author(s) Note: Makale, Yıldız Teknik Üniversitesi Sosyal Bilimler Enstitisü Türk Dili ve Edebiyatı Anabilim Dalı'nda hazırlanan "Yaşar Kemal ve Dido Sotiriyu'nun Romanlarında Toplumsal Bellek" başlıklı doktora tezinden üretilmiştir. / The article was produced from the PhD thesis titled "Social Memory in the Novels of Yaşar Kemal and Dido Sotiriyu" prepared in the Department of Turkish Language and Literature, Ylldiz Technical University Institute of Social Sciences.

Katkı Oranı / Author Contributions: Tez danıșmanı olan ikinci yazar kuramsal çerçeve ve literatür konularında destek sağlamıștır. / The second author, who was the thesis advisor, provided support for the theoretical framework and literature. 